\title{
Serum Leptin in Patients with Chronic Renal Failure on Different Modes of Management
}

\author{
Hala M. EL-Mougi*, Samiha Abo EL-Yazeed **, Zeinab A. Yousry** and \\ Abir Abdel Fattah ** \\ Departments of Medical Biochemistry* and Internal Medicine** Faculty of Medicine \\ (Girls), AL-Azhar University
}

\begin{abstract}
:
Aim: To study serum leptin level in chronic renal failure (CRF) patients on different modes of management and to analyze the impact of the mode of therapy on serum leptin level.

Subjects and Methods: This study was conducted on 64 patients (33males\&31females) with chronic renal failure divided into three groups: group I: Twenty-six patients treated conservatively and did not start dialysis yet (predialysis), group II: Twenty-four patients treated by hemodialysis, group III: Fourteen patients treated by continuous ambulatory peritoneal dialysis (CAPD). Twenty healthy subjects were included as control group. All patients and controls were subjected to full clinical examination including height and weight to calculate body mass index (BMI). Blood urea and serum creatinine were measured as renal function tests. Serum leptin was measured by EASIA and so serum insulin.

Results: In predialysis and CAPD groups, there is a significant increase in leptin, leptin/ $\mathrm{BMI}$ and insulin in patients in comparison to control subjects. In hemodialysis group, there is a significant increase in leptin and leptin/ BMI and a non-significant increase in insulin level in patients in comparison to control subjects. Insulin is significantly correlated with leptin in the first group, while in the second and third groups there is no correlation. The highest leptin level is found in the CAPD group of patients followed by the predialysis one then the hemodialysis group.

Leptin level is significantly higher in females than males in all groups. This difference remained after adjusting leptin level to BMI.

No correlation was found between leptin level and age or between leptin level and renal function in the three groups of patients. No correlation was found between leptin level and the duration of dialysis in the hemodialysis and CAPD groups.

Conclusion: Serum leptin is elevated in CRF patients irrespective of the type of management they are undergoing. Dialysis, has no significant effect on leptin level. The two main predictors of serum leptin level are sex and BMI in CRF patients and in healthy subjects. Leptin level may serve as a valuable clinical marker for body adiposity.
\end{abstract}

\section{Introduction}

Leptin is a $16 \mathrm{KD}$ protein hormone produced mainly by white adipose tissue (Kuwahara et al., 2003). It is involved in energy homeostasis that acts to inhibit food intake, to stimulate energy expenditure and influence insulin secretion, lipolysis and sugar transport (Mistrik et al., 2004).

The action of leptin is mediated through the leptin receptor(Ob-R), which is encoded by the diabetes (db) gene. Leptin receptors isoforms have been reported in wide variety of tissues: heart, lung, placenta, liver, muscle, kidney, pancreas, small intestine, colon, testes, ovary, prostate and brain (Hardwich et al.,2001)).

Both the structure of leptin and its receptor suggest that leptin should be classified as a cytokine (Madej et al., 1995).

Hyperleptinemia is an essential feature of human obesity as leptin is highly correlated with the percentage of body fat and body mass index (Haupt et al., 2005).A decrease in the body weight resulted in a 
significant decrease in serum leptin in old adults (Miller et al., 2004).

In infants, serum leptin was highly correlated with body mass index (BMI), maternal and cord blood leptin and birth weight were all positively correlated indicating that leptin concentrations signals energy status from fetal life onwards (Collinson et al., 2005). Strong sex difference in leptin levels existed at birth with leptin levels significantly higher in females. This difference disappeared at 8 weeks and reappeared at 16 weeks (Collinson et al., 2005).

Leptin level was found to be higher in insulin resistant subjects than in insulin sensitive ones (Papadia et al., 2003).A combination of insulin and dexamethasone doubled leptin release by adipocytes taken from massively obese human subjects (Kanu et al., 2003).

Circulating levels of leptin have a distinct diurnal and circadian rhythm, with minimum values during daytime and a nocturnal rise with maximum values during early to mid sleep (Mullington et al., 2003).

Chronic renal failure (CRF) is a complex syndrome characterized by a progressive and generally irreversible decline in glomerular filtration rate (GFR), and is frequently accompanied by hypertension, susceptibility to infection and generalized deterioration in organ function (Christopher, 2000). Leptin level is influenced by sex in chronic renal failure as in normal subjects being higher in females (Bossola et al., 2004).

In North Africa including Egypt, the incidence of renal disease is much higher than that in the West. In Egypt the incidence of end stage renal disease is 74 per million population (pmp)/ year and the prevalence of patients on replacement therapy is $264 \mathrm{pmp}$ (Barsoum, 2003).

As the kidney has been shown to be the principle site of elimination of circulating leptin in healthy subjects, it is reasonable to predict that leptin accumulates in renal failure(Sharma et al., 1997). Several studies found that uraemic patients, had elevated serum leptin levels (Pedro et al.,2002 \& Krisova et al., 2003).
Some patients (especially males with low BMI and low plasma insulin levels) have normal or even low leptin levels suggesting that other tissues may become more active in leptin removal from plasma (Fouque et al., 1998).

Hyperinsulinemia may be a cause for increased leptin production in CRF as a direct correlation was reported between insulin and leptin levels in these patients (Krizova et al. 2003). Another possible reason for elevated leptin levels in renal failure is chronic inflammation, as it has been demonstrated that cytokines such as TNF- $\alpha$ and IL-1, induce both increase in leptin mRNA concentrations and anorexia in animals (Krizova et al.,2003).

The aim of this work was to study serum leptin level in chronic renal failure patients on different therapeutic modalities and to analyze the impact of the mode of therapy on serum leptin level.

This study also aimed at studying serum insulin level in chronic renal failure patients and exploring its relationship with leptin.

\section{Subjects \& Methods}

This study was conducted on 64 chronic renal failure patients from the internal medicine department of Al-Zahraa Hospital, Al Azhar University and AlMatarria National Institute of Urology and Nephrology.

The patients were 33 males and 31 females, their age ranged between 21 and 60 years and were divided into three groups:

Group I: Included 26 patients 13 male and 13 females with impaired renal function on conservative therapy and did not start replacement therapy yet (predialysis group).

Group II: Included 24 patients 13 males and 11 females on haemodialysis.

Group III: Included 14 patients 7 males and 7 females on continuous ambulatory peritoneal dialysis (CAPD).

Twenty healthy subjects 8 males and 12 females were included as a control 
group. Their age ranged between 25 and 60 years .

Patients and control subjects with diabetes mellitus, massive obesity and chronic manifested liver disease were excluded from the study as leptin level may be affected by these diseases.

\section{All patients and control subjects were subjected to:}

I) Full history: including age, sex, symptoms of renal disease, disease duration and dialysis duration for patient, groups.

II) Full clinical examination including measuring the height and body weight to calculate the body mass index (BMI).

$$
\mathrm{BMI}\left(\mathrm{kg} / \mathrm{m}^{2}\right)=\frac{\text { Body weight }(\mathrm{kg})}{(\text { Height in metres })^{2}}
$$

(John and Kral, 2001)

III) Laboratory investigation:

- Kidney function tests including serum creatinine,uric acid \&urea .

- Fasting blood glucose.

- Liver function tests including serum albumin, AST \&ALT.

- Serum leptin level was measured by EASIA an enzymometric assay for quantitative measurement of human leptin in serum and plasma (Biosource Europe S.A.) (Friedman and Halass, 1998).

- Fasting serum insulin was measured by EASIA, an enzymometric assay for quantitative measurement of human insulin in serum and plasma (Biosource Europe S.A.) (Flier et al., 1979).

\section{Statistical Analysis:}

SPSS statistical software package, V. 9.02, Echosoft Corp. USA, 1998 was used for data analysis. The probability of error at 0.05 was considered significant while at 0.01 and 0.001 are highly significant (Sokal and James,1995).

\section{Results}

The results revealed a non significant increase $(\mathrm{P}>0.05)$ of serum leptin among all patients compared to control subjects (Table 1). The level of serum leptin among CAPD patients was higher than its level among predialysis patients which in turn was higher than that among haemodialysis patients (Table 2 \&Fig 1 ).

Regarding levels of serum insulin there was a highly significant statistical increase $(\mathrm{P}<0.001)$ in its level among all patients compared to control subjects (Table 1). Its level was highly significant increased $(\mathrm{P}<0.001)$ in predialysis patients, while it was non-significantly increased $(\mathrm{P}>0.05)$ among haemodialysis patients compared to control subjects. There was also a significant statistical increase $(\mathrm{P}<0.05)$ in its level among CAPD patients compared to control subjects (Table 2 \&Fig 1).

Serum leptin level showed a statistical highly significant increase $(\mathrm{P}<0.001)$ in females compared to that of males in the three patient groups and in the control group. This increase remained after adjustment for the BMI where leptin/BMI in females showed a statistical highly significant increase $(\mathrm{P}<0.001)$ compared to that of males in the four groups (Table 3 \&Fig2).

Regarding results of serum insulin there was no statistically significant difference $(\mathrm{P}>0.05)$ between males and females (Table3 \&Fig2). There was a positive correlation between serum leptin and serum insulin in both patients and control subjects but this correlation is statistically significant only in the predialysis group ( $\mathrm{r}=0.370$ ) (Fig3).

Table 4 shows a significant correlation between leptin and BMI, but neither significant correlation between leptin and age, nor between leptin and parameters of renal function (s. creatinine, bl. Urea and s. uric acid) was shown. 
Table (1): Mean \pm SD of serum leptin and serum insulin among all patients compared to control subjects

\begin{tabular}{|c|c|c|c|}
\hline & Control (20) & C.R.F patients (64) & P \\
\hline S. leptin $(\mathbf{n g} / \mathbf{m l})$ & $12.137 \pm 10.966$ & $26.152 \pm 32.519$ & $>0.05$ (N.S.) \\
\hline F.S. Insulin $(\mu \mathrm{U} / \mathbf{m l})$ & $3.879 \pm 1.553$ & $6.904 \pm 4.412$ & $<0.001$ (H.S.) \\
\hline
\end{tabular}

Table (2): Mean \pm SD of serum leptin and serum insulin levels among predialysis, haemodialysis and CAPD groups compared to the controls

\begin{tabular}{|c|c|c|c|c|}
\hline & Control & Predialysis & Haemodialysis & CAPD \\
\hline \multirow{3}{*}{ S. leptin (ng/ml) } & & $27.306 \pm 31.562$ & $18.118 \pm 20.378$ & $37.783 \pm 46.979$ \\
& $12.137 \pm 10.965$ & $\mathrm{P}>0.05$ & $\mathrm{P}>0.05$ & $\mathrm{P}>0.05$ \\
& & (N.S.) & (N.S.) & (N.S.) \\
\hline $\begin{array}{c}\text { F.S. insulin } \\
(\mu \mathrm{U} / \mathrm{ml})\end{array}$ & $3.879 \pm 1.553$ & $7.562 \pm 4.133$ & $5.942 \pm 4.095$ & $7.33 \pm 5.391$ \\
& & $\mathrm{P}<0.001$ & $\mathrm{P}>0.05$ & $\mathrm{P}<0.05$ \\
& & (H.S.) & (N.S.) & (S.) \\
\hline
\end{tabular}

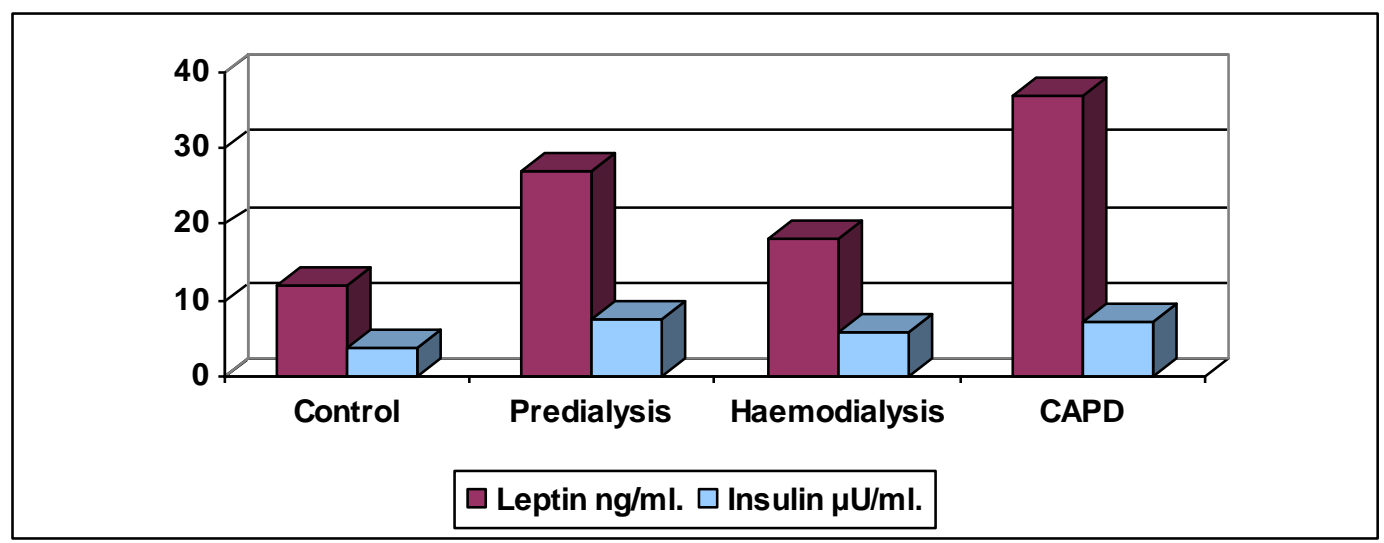

Figure (1): Comparison between controls, predialysis, haemodialysis and CAPD regarding mean values of serum leptin and serum insulin.

Table (3):Mean \pm SD serum leptin, BMI, leptin/BMI, and serum insulin levels in males compared to females among different studied groups

\begin{tabular}{|c|c|c|c|c|c|c|c|c|}
\hline & \multicolumn{2}{|c|}{ Control } & \multicolumn{2}{|c|}{ Predialysis } & \multicolumn{2}{|c|}{ Haemodialysis } & \multicolumn{2}{|c|}{ CAPD } \\
\hline & ales & Fem & ales & Females & Iales & Females & ales & Females \\
\hline $\begin{array}{c}\text { S. } \\
\text { leptin } \\
(\mathrm{ng} / \mathrm{ml})\end{array}$ & 2.57 & $\begin{array}{c}18.512 \pm 9.707 \\
\text { P }<0.001 \\
\text { (H.S.) }\end{array}$ & 4.07 & $\begin{array}{c}50.541 \pm 30.032 \\
\mathrm{P}<0.001 \\
\text { (H.S.) } \\
\end{array}$ & 7.01 & $\begin{array}{c}31.243 \pm 23.352 \\
\text { P }<0.001 \\
\text { (H.S.) }\end{array}$ & 7.24 & $\begin{array}{c}68.323 \pm 50.881 \\
\mathrm{P}<0.001 \\
\text { (H.S.) }\end{array}$ \\
\hline $\begin{array}{c}\mathrm{BMI} \\
\mathrm{kg} / \mathrm{m}^{2}\end{array}$ & $25.975+4.870$ & $\begin{array}{c}28.867+5.926 \\
\mathrm{P}>0.05 \\
(\mathrm{NS})\end{array}$ & $24.908+3.471$ & \begin{tabular}{|c|}
$32.292+7.22$ \\
P $<0.01$ \\
(H.S.)
\end{tabular} & $25.931+5.837$ & $\begin{array}{c}27.818+6.657 \\
\mathrm{P}>0.05 \\
(\mathrm{NS})\end{array}$ & $24.729+2.125$ & $\begin{array}{c}31.671+8.887 \\
\mathrm{P}>0.05 \\
(\mathrm{NS})\end{array}$ \\
\hline $\begin{array}{c}\text { Leptin/ } \\
\text { BMI }\end{array}$ & $0.0963 \pm 0.0681$ & $\begin{array}{c}0.6539 \pm 0.3513 \\
P<0.001 \\
\text { (H.S.) }\end{array}$ & $0.1604 \pm 0.0629$ & $\begin{array}{c}1.5187 \pm 0.8416 \\
\mathrm{P}<0.001 \\
\text { (H.S.) }\end{array}$ & $0.2412 \pm 0.2006$ & $\begin{array}{c}1.0471 \pm 0.6056 \\
\text { P }<0.001 \\
\text { (H.S.) }\end{array}$ & $0.2757 \pm 0.0995$ & $\begin{array}{c}2.0716 \pm 1.5484 \\
\mathrm{P}<0.001 \\
\text { (H.S.) }\end{array}$ \\
\hline \begin{tabular}{c|}
$\mathbf{S}$. \\
insulin \\
$\mu \mathrm{U} / \mathrm{ml}$
\end{tabular} & $3.379 \pm 0.943$ & $\begin{array}{c}4.213 \pm 1.816 \\
\mathrm{P}>0.05 \\
\text { (N.S.) }\end{array}$ & $7.394 \pm 3.693$ & $\begin{array}{c}7.73 \pm 4.678 \\
P>0.05 \\
\text { (N.S.) }\end{array}$ & $6.398 \pm 4.611$ & $\begin{array}{c}5.402 \pm 3.53 \\
\mathrm{P}>0.05 \\
\text { (N.S.) }\end{array}$ & $6.716 \pm 5.07$ & $\begin{array}{c}7.943 \pm 6.033 \\
\text { P }>0.05 \\
\text { N.S. }\end{array}$ \\
\hline
\end{tabular}




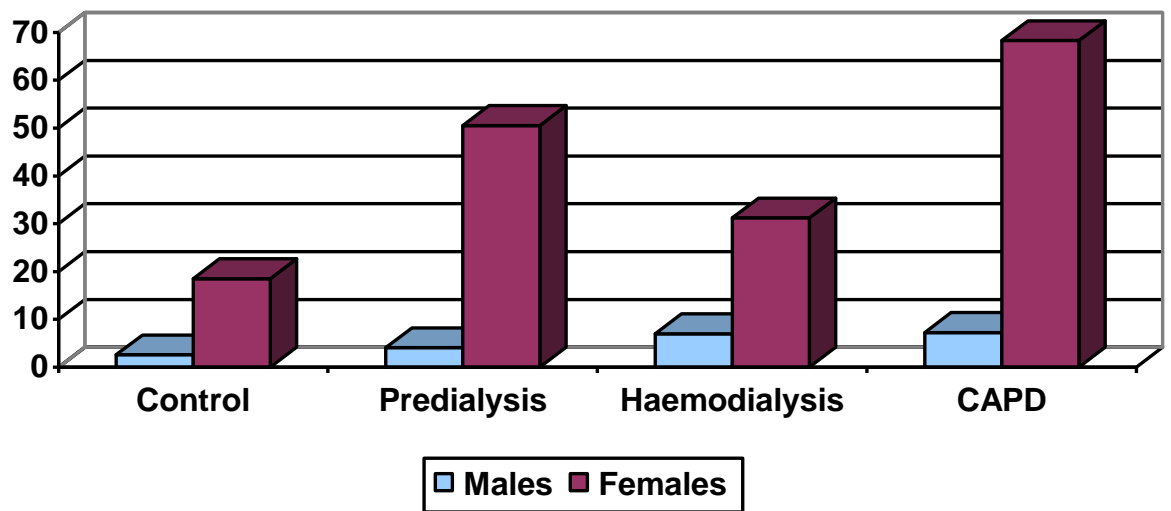

Figure (2): Comparison between males and females among each of control, predialysis, haemodialysis and CAPD regarding mean values of serum leptin

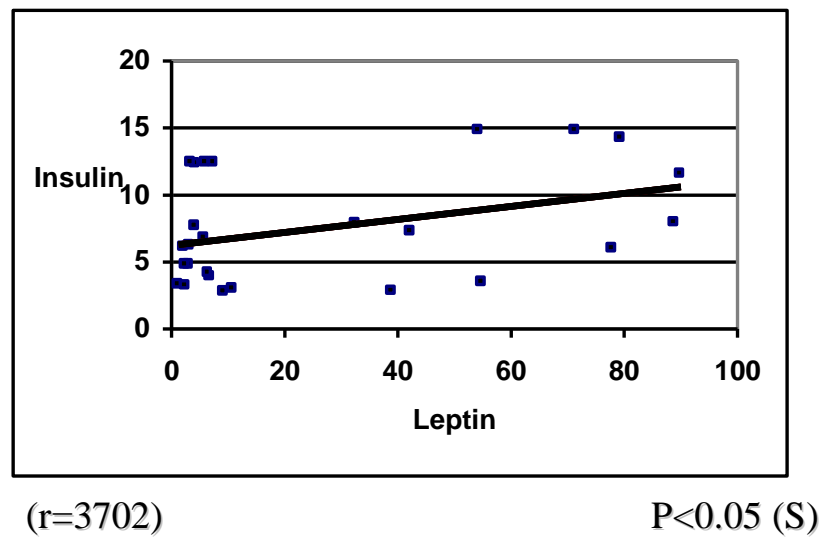

Figure (3): Linear regression analysis showing correlation between $s$. leptin and s. insulin among predialysis patients.

Table (4): Main correlations of leptin among patients and control subjects

\begin{tabular}{|l|l|l|}
\hline & Control & Patients \\
\hline Age & -0.090 & -0.084 \\
& (N.S.) & (N.S.) \\
\hline BMI & 0.391 & 0.646 \\
& (S.) & (S.) \\
\hline Insulin & 0.271 & 0.159 \\
& (N.S.) & (N.S.) \\
\hline S. creatinine & 0.169 & -0.191 \\
& (N.S.) & (N.S.) \\
\hline Bl. Urea & -0.045 & -0.128 \\
& (N.S.) & (N.S.) \\
\hline S. uric acid & 0.176 & -0.030 \\
& (N.S.) & (N.S.) \\
\hline
\end{tabular}

Note: The table gives correlation coefficients ( $\mathrm{r}$ value) by linear regression analysis. 


\section{Discussion}

Leptin is the protein product of the ob gene, secreted mainly by white adipose tissue (Choi et al., 2005). It is a pleiotropic hormone involved in energy homeostasis, neuroendocrine and hematopoitic function, inflammation and immunity (Ottonello et al., 2004).

Leptin is partly cleared by the kidney and has been reported to increase in chronic renal failure (Stamatiadis et al., 2004 and Bossola et al., 2004).Chronic renal failure is often accompanied by hyperleptinemia caused by deficient renal metabolism of leptin and possibly increased leptin production which in turn may result from hyperinsulinemia and increased proinflammatory cytokine levels in patients with CRF (De-Precigout et al., 2000).

The increasing incidence of end stage renal disease in Egypt has made CRF and its management a serious health problem. Hemodialysis constitutes the most frequent modality of renal replacement therapy while continuous ambulatory peritoneal dialysis (CAPD) is used sporadically (Barsoum, 2003). The third annual report of the Egyptian Society of Nephrology (1998) states that $97.2 \%$ of patients with CRF on replacement therapy in Egypt are treated by heamodialysis, while peritoneal dialysis is used in $2.8 \%$ of cases only.

In the present work we studied serum leptin level in chronic renal failure patients on different modes of management: conservative therapy, hemodialysis and continuous ambulatory peritoneal dialysis (CAPD).

Body mass index (BMI) was used as a measure of adiposity in this study. Leptin level for each patient and control subject was divided by the BMI of subjects to get leptin level adjusted for BMI.

In the present study serum leptin level in patients with CRF was non-significantly increased $(\mathrm{P}>0.05)$ than that of control subjects. Fontan et al. (1999) and Obineche et al. (2002) found a significant increase in leptin level in CRF patients compared to that of control subjects.
In this study the variability of leptin level in CRF patients was very wide. This may be explained by the fact that serum leptin level in CRF is influenced by many factors. Apart from decreased renal clearance, gender BMI, the level of serum insulin and proinflammatory cytokines may influence leptin level (Zheng et al., 2002).

Hyperinsulinemia and insulin resistance are common in CRF (Krizova et al., 2003). The results of the present study show a highly significant increase $(\mathrm{P}<0.01)$ in serum insulin level in all patients compared to that of control subjects. This is in agreement with the findings of Obeniche et al. (2002) and Krizova et al. (2003).

There is a non-significant positive correlation( $\mathrm{r}=0.1587, \quad \mathrm{P}>0.05) \quad$ between leptin and insulin in CRF patients in this study. This is consistent with the results of De-Precigout et al. (2000) and Pedro et al. (2002).

The present study shows a positive significant correlation between serum leptin and BMI in CRF patient $(\mathrm{r}=0.646, \mathrm{P}<0.05)$. This is in agreement with results of Pedro et al. (2002) and Wang et al. (2003), who found that leptin concentration in end stage renal disease patients correlated directly with body mass index in males and females.

In the predialysis group of patients, the results of the present study demonstrates a significant increase $(\mathrm{P}<0.05)$ in serum leptin and leptin/ BMI in male patients over male control subjects and a highly significant increase $(\mathrm{P}<0.001)$ in serum leptin and leptin/ BMI in female patients over female control subjects. Leptin levels are significantly higher $(\mathrm{P}<0.001)$ in females than males.These findings are in agreement with the findings of Obeniche et al. (2002) and Vignioble et al. (2002), who reported a high significant increase of serum leptin in chronic renal failure patients than in control subjects and a significant correlation between serum leptin and BMI.

Insulin level in the predialysis group is highly significantly increased $(\mathrm{P}<0.001)$ 
compared to the control subjects, and there is a positive significant correlation $(\mathrm{P}<0.05)$ between insulin and leptin, these results coincide with those of Fontan et al. (1999) and Obeniche et al. (2002), who found a significant correlation between serum leptin and insulin concentrations.

In contrast to these results DePrecigout et al. (2000) stated that the correction of hyperinsulinemia and insulin resistance in patients with CRF is not accompanied by an improvement in hyperleptinemia.

In the group of patients treated by haemodialysis, the results of this study demonstrate a significant increase $(\mathrm{P}<0.05)$ in leptin level in patients compared to male control subjects. This is in agreement with the results obtained by Wang et al. (2003) and Stamatiadis et al. (2004)who found that leptin levels were higher in haemodialysis patients versus controls.

In female patients leptin level shows a non-significant increase $(\mathrm{P}>0.05)$ compared to control subjects. This is consistent with the findings of Kagan et al. (1999) while leptin/ BMI shows a significant increase $(\mathrm{P}<0.05)$ compared to control subjects.

Merabet et al. (1997) reported that: the rate of increase in serum leptin per unit BMI is higher in CRF patients than normal subjects.

Odamaki et al. (1999) stated that leptin level in haemodialysis patients was not significantly different from that of the control subjects although patients showed lower BMI.

Nordfors et al. (1998) reported a significant decrease in ob gene expression in CRF patients with an inverse correlation ob gene expression and leptin suggesting that hyperleptinemia in CRF down regulates ob gene expression.

Comparing serum leptin level of patients treated by haemodialysis with that of predialysis patients, no significant difference was observed $(\mathrm{P}>0.05)$. This indicates that haemodialysis treatment has no significant effect on serum leptin. Hiemburger et al. (1997) found no significant change in body fat content or leptin level in patients with CRF after 12 months of haemodialysis. Also, Widjaja et al. (2000), reported that leptin is poorly cleared by low flux hemodialysis.

Serum insulin level in this group of patients shows a non significant increase (P>0.05) compared to control subjects. Leptin is not correlated with insulin. This is in agreement with the results of DePrecigout et al. (2000), who found that there was no correlation between insulin and leptin levels.

The absence of correlation between leptin and insulin in this group of patients may be explained by the low degree of insulin resistance indicated by low insulin level. Segal et al. (1996) stated that the difference in insulin sensitivity could result in different patterns of leptin response to physiological stimuli.

Kagan et al. (1999) reported that the peritoneal clearance of leptin accounts for a small percentage of the daily leptin production. Arkuche et al. (1999) reported that leptin is eliminated by peritoneal dialysis although its clearance is restricted as compared with peritoneal clearance of smaller molecules such as urea and creatinine.

In the group of patients on CAPD treatment the results of the present study demonstrates a highly significant increase $(\mathrm{P}<0.01)$ in serum leptin and leptin/BMI in male patients over male control subjects and a significant increase $(\mathrm{P}<0.05)$ in serum leptin and leptin/BMI in female patients over female control subjects.

Leptin level shows a highly significant increase $(\mathrm{P}<0.001)$ in female over male patients in the same group. These results are in agreement with the results of Obeniche et al.( 2002) who found that the mean leptin levels were 5 folds higher among CAPD-treated men and 7.5 fold higher among females of the same group.

Hyperleptinemia in CAPD patients was out of proportion of obesity as evidenced by high leptin/ BMI. This was also reported by (Vignioble et al., 2002).

Serum leptin level in this group of patients was higher than its level in the predialysis and hemodialysis groups of patients.This is consistent with the findings of Hiemburger et al. (1997) and Fontan et 
al. (1999), and may be explained by the fact that visceral fat accumulates in patients treated by CAPD and may be a source of leptin production. Hamilton et al. (1995) stated that omental adipocytes strongly expressed leptin mRNA in obese patients.

Insulin level in CAPD patients is significantly increased $(\mathrm{P}<0.05)$ compared to control subjects. Leptin level was poorly correlated with insulin. This is consistent with the results of Pedro et al. (2002) but against that of Fontan et al. (1999) and Obeniche et al. (2002).

No correlation is found between serum leptin and age, or between serum leptin and duration of dialysis. This agrees with the results of Merabet et al. (1997) and Fontan et al. (1999), who reported that there was no correlation between leptin levels and the number of years patients had been on dialysis.

\section{References}

1. Arkouche W, Julliard L, Delawari E, Lasne Y, Canbarnous $J$ and Fouque D (1999): Peritoneal clearance of leptin in continuous ambulatory peritoneal dialysis Am. J. Kidney. Dis., 34 (5): 839-44.

2. Barsoum R S (2003): End stage renal disease in North Africa Kidney International vol.63 supp.83: 111-4.

3. Bossola M, Muscaritoli M, Valenza V, Panocchia N, Tazza L, Fanelli F R and Luciani G (2004): "Anorexia and serum leptin levels in hemodialys:s patients." Nephron. Clin. Pract., 97 (3): 76-82.

4. Choi JH, Park SH, Leung PC and Choi KC (2005): "Expression of leptin receptor and potential effects of leptin on the cell growth and activation of mitogen-activated protein kinase in ovarian cancer cells", J. Clin. Endocrinol. Metab., 9 (1): 207-10.

5. Christopher G (2000): Clinical evaluation and manifestation of chronic renal failure. Comprehensive clinical nephrology. Sec.14 Chapt 68.

6. Collinson A, Moore S, O'Connell M, Charalambos C and Prentice A (2005): "Developmental changes in leptin as a measure of energy status in human infants in a natural ecologic setting" Am. J. Clin. Nutr., 81(2):488-94.

7. De-Precigout V, Chauveau P, Delclaux C, El-Haggan $W$ and Baillet $L$ (2000):
"No change of hyperleptinemia despite a decrease in insulin concentration in patients with chronic renal failure on a supplemented very low protein diet" Am. J. Kidney. Dis., 36 (6): 1201-6.

8. Egyptian Society of Nephrology (1998): "Types of dialysis". $3^{\text {rd }}$ annual report.

9. Flier J S, Kahn C R and Roth J (1979): "Receptor antireceptor antibodies and mechanism of insulin resistance" N. Engl. J. Med., 300 (8): 413-9.

10. Fontan M P, Rodriguez-Carmona A, Cordido F and Garcia-Buela J (1999): "Hyperleptinemia in uremic patients undergoing conservative management peritoneal dialysis, and hemodialysis: A comparative analysis" Am.J.Kidney.Dis., 34 (5): 82431.

11. Fouque D, Juillard L, Lasne Y, Tabakian Laville M, Odile and M Joly (1998): "Acute leptin regulation in end-stage renal failure: The role of growth hormon and IGF-1." Kidney Int., 54: 932-7.

12. Friedman J H and Halass J L (1998): "Leptin and regulation of body weight in mammals." Nature., 395: 763-70.

13. Hamilton B S, Pahlia D, Kwan A Y M and Deitel M (1995): "Increased obese mRNA expression in omental fat cells from massive obese humans". Nature Med., 1: 953-6.

14. Hardwich JC Van Den Brink GR and Offerhaus GI et al. (2001): Leptin is a growth factr for colonic epithelial cells. Gastroenterol.,121:79-90.

15. Haupt D W, Luber A, Aaeda J, Melson A $\mathbf{K}$, Schweigerr $\mathbf{J} A$ and Newcomer $\mathbf{J}$ W (2005): "Plasma leptin and adiposity during antipsychotic treatment of schizophrenia" Neurophsycho Pharmacology. 30 (1): 184-91

16. Heimburger O, Lonnquist F, Danielsson A and Nordenstrom J (1997): "Serum immunoreacive leptin concentration and its relation to the body fat content in chronic renal failure" J. Am. Soc. Nephrol., 8 (9): 1423-30.

17. John G and Kral A (2001): "Morbidity of severe obesity". Surgical Clinics of North America, 81 (5): 1-22.

18. Kagan A, Haran N, Leschinsky L, Shuali N and Rapopprt J (1999): Leptin in CAPD patients: serum concentration and peritoneal loss. Nephrol. Dial. Transplant, 14(2): 400-5.

19. Kanu A, Fain $J$ N, Bahouth $S W$ and Cowan G S (2003): "Regulation of leptin release by insulin, glucocorticoids, G (i):coupled receptor agonists and pertussis 
toxin in adipocytes and adipose tissue explants from obese humans in primary culture". Metabolism, 52(1): 60-6.

20. Krizova J, Sulkova S, Beduarova V, Parizkova J, Kotrlikorva E and Haluzik M (2003): "Soluble leptin receptor levels in patients with chronic renal failure". Physiol. Res., 52 (3): 347-51.

21. Kuwahara H, Uotani S, Abe T, Degawa Y M, Takahashi R and Kita A (2003): "Insulin attenuates leptin induced STAT3 tyrosin phosphorylation in a hepatoma cell line.” Mol. Cell. Enocrinol. ,205 (1-2): 115120.

22. Madej T, Boguski M S and Bryant S H. (1995): "Threading analysis suggests that the obese gene product may be a helical cytokine." FEBs Lett: 23; 373(4):13-8.

23. Merabet E, Dagogo-Jack $S$ and Coyne $D$ W (1997): Increased plasma leptin concentration in end stage renal disease $\mathrm{J}$. Clin. Endocrinol. Metab.,82(3):847-50.

24. Miller G D, Nichlas B J, Davis C C, Loeser R F and Messier S O (2004): "Is serum leptin related to physical function and is it modifiable through weight loss and exercise in older adults with knee osteoarthritis" Int. J. Obes. Relat. Metab. Disord., 28 (11): 1383-90.

25. Mistrik P, Moreau F and Allen JM (2004): "Bia Core analysis of leptin-leptin receptor interaction: evidence for 1:1 stoichiometry" Anal. Biochem. 327 (2): 271-7.

26. Mullington J M, Chan J L, Van and Dongen H P A (2003): "Sleep loss reduces diurnal rhythm amplitude of leptin in healthy men" Journal of Neuroendocrinology Vol. 15: 851-4.

27. Nordfors $L$, Longvist $F$ and Heimburger O (1998): "Low leptin gene expression and hyperleptinaemia in chronic renal failure" Kidney. Int., 54: 1267-75.

28. Obineche E N PT, Gillett M, Abdulle A, Sulaiman $M$ and AL-Rokhaimi $M$ (2002): "Leptin and lipid metabolism related hormones in chronic renal failure in Arabia". Nephrology, 7:115-20.

29. Odamaki M, Furuy R, Yoneyama T, Nishikino M, Hibi I, Miaji $K$ and Kumagai H (1999): "Association of serum leptin concentration with weight loss in chronic hemodialysis patients." Am. J. Kidney Dis., 33 (2): 361-8.
30. Ottonello L, Gnerre $P$, Mancini $M$, Dapino P, Russo R, Ganibotto G, Barreca T and Dallegri F (2004): "Leptin as a uremic toxin interferes with neutrophil chemotaxis": J. Am. Soc. Nephrol., 15 (9): 2366-72.

31. Papadia F, Marinari G M, Camerini G, Scopinaro N and Adami G F (2003): "Leptin and insulin action in severely obese women.” Obes. Surg., 13 (2): 241-4.

32. Pedro I, Juan-Jose D, Ma-Jose F R, MeAuxiliadore $B$ and Abelardo A (2002): "Effect of short-term human growth hormone therapy on plasma leptin concentration in dialysis patients" Nephrol. Dial. Transplant., 17(2): 260-4.

33. Segal K R, Landt $M$ and Klein S (1996): "Relationship between insulin sensitivity and plasma leptin concentration in lean and obese men." Diabetes, 45: 988-91.

34. Sharma K, Considine $\mathbf{R}$ V and Beckie $M$ (1997): "Plasma leptin is partly cleared by the kidney and is elevated in haemodialysis patients" Kidney Int., 51 (6): 1980-5.

35. Sokal $R$ and James $E$ (1995): Rhalfbiometry: the principles and practice of statistics in biological research. $2^{\text {nd }} \mathrm{ed}$, New York.

36. Stamatiadis D N, Chan J L, Cogswell R, Stephanopoulou $\mathbf{H}$ C, Bullen $J$ and Mantzoros C S (2004): "Elevated leptin fragments in renal failure correlate with BMI and hematopoiesis and are normalized by hemodialysis." Clin. Endocrinol., 60 (4): 434-41.

37. Vignioble $M$, Brichard $S$ and Jadoul $M$ (2002): "Serum leptin concentration in peritoneal dialysis patients determinants, longitudind evaluation and circadian rhythm". Acta. Clin. Belg., 56(3): 173-9.

38. Wang J, Liu Hawkins M, Barzilai $\mathbf{N}$ and Rossetti L (2003): "A nutrient-sensing pathway regulates leptin gene expression in muscle and fat" . Nature., 393(6686):684-8.

39. Widjaja A, KielsteinJ, Horn R, KleimV and Barabant $G$ (2000): Free serum leptin but not bound leptin concentrations are elevated in patients with end stage renal disease Nephrol. Dal. Transplant, 15 (6): 846-50.

40. Zheng F, Qiu X, Yin S and Li Y (2002): "Changes in serum leptin levels in chronic renal failure patients with metabolic acidosis” J. Ren. Nutr., 11 (40): 207-11. 


\title{
ليبتين مصل دم مرضى الفشل الكلوى المزمن الخاضعين لطرق علاج مختلفة
}

\author{
هالة محمد الموجى * , سميحة أبو اليزيد عبدربة*** ,زينب أحمد يسرى*** و عبير عبد

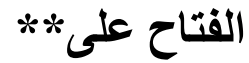 \\ أقسام الكيمباء الحيوية الطبية* و الباطنة العامة*** كلية طب الأزهر بنات
}

يعتبر اللبتين هرمون بروتينى تفرزه الخلايا الدهنية فى الجسم و لذلك فان مستو اهن في الدام

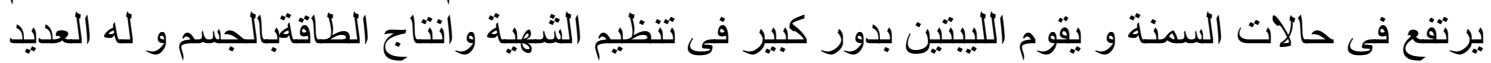

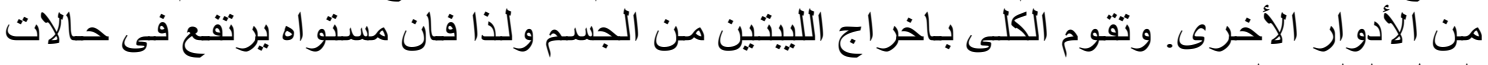

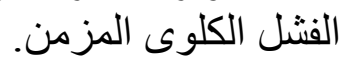
وقد أجريت هذه الدر اسة على 64 من مرضى الفنل الكلوى المزمن (33 ذكور و 31 إناث)

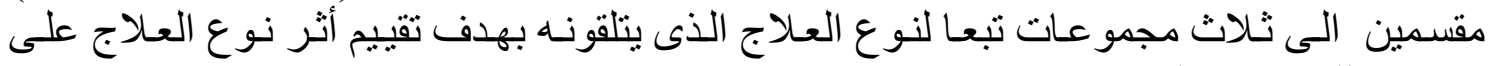

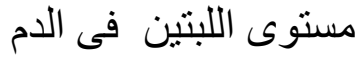
المجموعة الأولى وتئكون من 26 مريضـا(13ذكور و 13 إناث) يعالجون بالعلاج التحفظى ولم

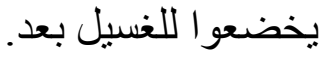
المجموعة الثانية:وتتكون من 24 مريضا(13ذكور و 11 إناث) يعالجون بالاستصفاء الدموى.

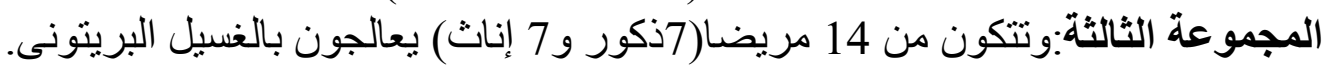

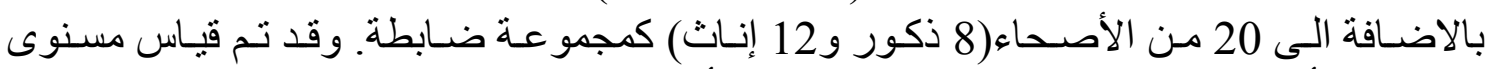

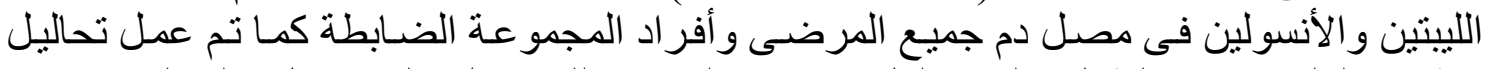

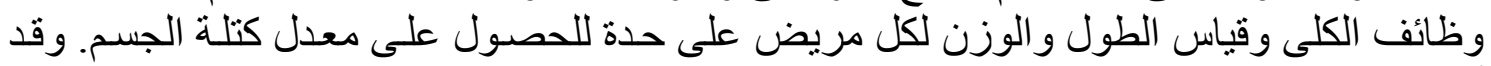

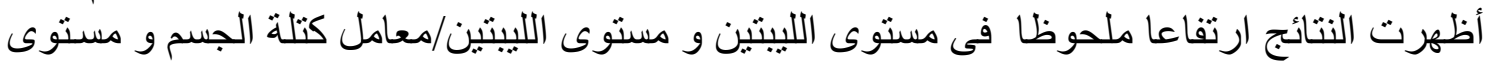

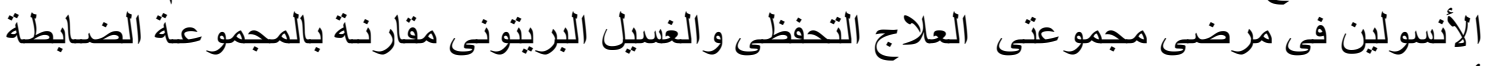

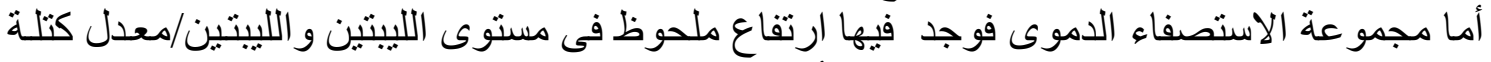

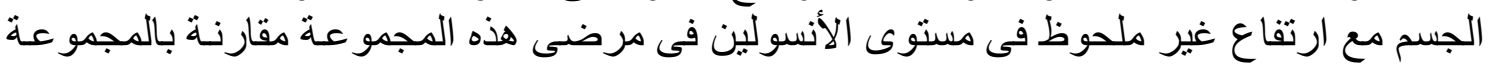
الضابطة. كما أظهرت النتائج وجود علاقة ايجابيه بين الأنسولين و الليبتين فى المجموعة الأولى ولم يثبت وجود هذه العلاقة فى المجمو عتين الثانية و الثالثة.

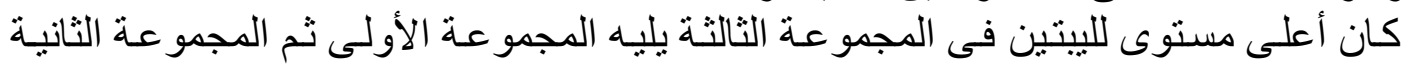

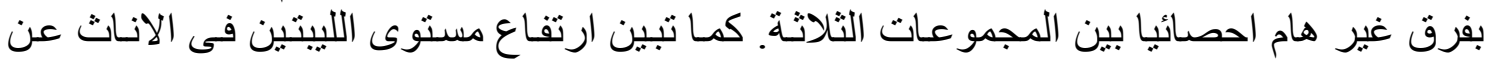

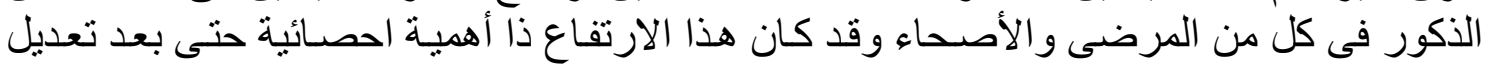

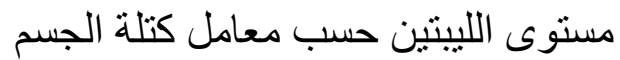
لم يظهر مستوى الليبتين ارتباطا بطول مدة الغسيل الكلوى سواء الجئ الدموى أو البريتونى.

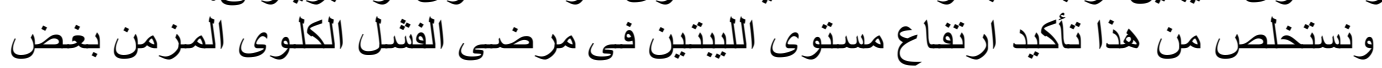

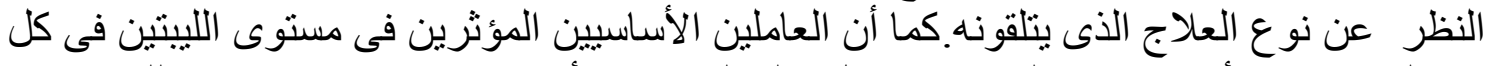

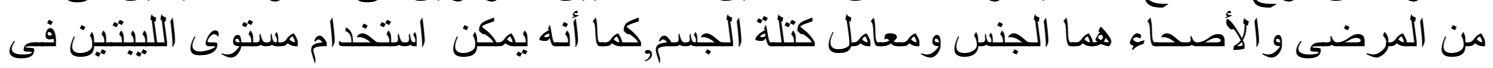

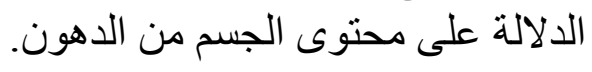

